\title{
An ethnopolitical conflict in Russia's Republic of Mari El in the 2000s: The study of ethnic politics under the authoritarian turn
}

The paper presents an analysis of the political confrontation between the new ruling group and the political opposition in the Republic of Mari El, which began in the early 2ooos and subsequently erupted into an open ethnopolitical conflict. Based on some theoretical perspectives on conflict and diversity management, the paper analyzes the structural characteristics and the dynamics of the conflict in Mari El. The analysis reveals that authoritarian tendencies in the republic largely contributed to the eruption of the conflict and predetermined the choice of methods of conflict management.

\section{Introduction}

In the early 200os, the authoritarian turn in Mari El provoked a political confrontation between the new ruling group and the opposition. The confrontation erupted into an open conflict when the tightening of the authoritarian regime resulted in the marginalization of the opposition. The conflict escalated after the republic's presidential elections in the end of 2004. The opposition protested against the rigged election results by arranging rallies and carrying out other unconventional political actions. In January 2005, a journalist and, a few days later, the leader of an organization of the ethnic Mari were beaten. The beatings continued later, too, and many among the victims were ethnic Mari leaders and activists.

The crimes remained unsolved, but it was widely believed that the beatings were connected to the political activities of the victims. The conflict became a point of international criticism of Russia and received broad coverage in both domestic and international media. After the two recent Chechen wars, gross human rights violations in Russia did not surprise 
the observers, who addressed the situation in Mari El from a human rights perspective (see, for example, Nyman 2006). The Russian authorities denied the existence of any conflict and accused foreign politicians of provocation. Indeed, after tens of thousands had been simultaneously killed in Chechnya and the North Caucasus, the killings of three journalists and beatings of several others in Mari El might have seemed a minor issue. Russian scholars backed the position of the authorities and interpreted the situation in Mari El as a power struggle between individual politicians, who, pursuing their own political ends, strived to instrumentally increase the salience of ethnic identities in order to mobilize public support (see, for example, Tiškov 2005).

The reluctance of the Kremlin to admit the existence of the conflict might find some explanations in the context of international relations. The united position of the Russian authorities and academia might be an example of how the scholarly discourse serves the interests of the authorities, which is another manifestation of the authoritarian turn in Russia. However, the conflict has not yet found due scholarly attention from the perspective of ethnic politics under the authoritarian turn. The instrumentalist account of the events provided only a partial explanation. For example, it fails to address the issue of the regime change and timing of the events. The conflictual situations characterized Russia's ethnic politics mainly during the democratic transition of the early 1990s. Why did ethnic politics in Mari El remain stable in the 1990s and only result in a conflict under the authoritarian tendencies of the 2000s?

The purpose of this study is to conduct an analysis of the conflict in Mari El in the light of existing theories of ethnicity and ethnic conflict in order to reveal the link between the political regime and conflict management. The Republic of Mari El is an interesting case where the establishment of an authoritarian regime not only coincided with the authoritarian turn in the Kremlin but also triggered a shift in the method of diversity management. In studying conflicts, scholars distinguish three levels of analysis: the international, domestic and individual levels (see Jesse \& Williams 2010). This paper will mostly explore the individual and domestic levels or, to be specific, the sub-state level. The paper will only briefly outline international aspects of the conflict and will not provide an analysis at the level of international relations or trans-border minority co-operation, or discuss the peculiarities of scholarly discourse under an authoritarian regime, which remain topics for further research. 
An analysis of ethnic politics and conflict at the sub-state level can benefit from a political mobilization perspective (see Wimmer, Cederman \& Min 2009). Theories of ethnic mobilization were developed, among others, within the instrumentalist and constructivist accounts of ethnicity. According to the instrumentalist account, ethnic elites might succeed in mobilizing popular support if they address the grievances that find resonance with the masses (see, for example, Giuliano 2011). According to a constructivist perspective, identities in the modern world are socially constructed but also durable phenomena. Ethnic mobilization might be recurrent not in a primordial sense but as an available resource and strategy. The constructivist perspective is compatible with institutionalism. Scholars have noted the central role of institutions in ethnic mobilization (see, for example, Gorenburg 2003). Ted Gurr's social movement theory established the link between ethnicity and conflict, which are connected through both social grievances and political opportunity structure (see Gurr 1993).

The paper will start by providing an overview of some conflict analysis tools in order to provide a foundation for the conceptualization of the events in Mari El. It also will briefly outline the political regime change in Russia and its impact on regional politics. Throughout the rest of the paper, the study will mostly concentrate on the analysis of regional politics. The bulk of the paper will explore the structural characteristics of the conflict in Mari El and its dynamics. As the conflict is relatively well documented in mass media, this study will present only an outline of the events, based on secondary sources and scientific literature.

Finally, the study will sum up the causes and characteristics of the conflict. The study will argue that the conflict was caused by the reliance of the new ruling group on ethnic domination as one of the methods of monopolization of power in the republic. This was a political conflict that acquired an ethnic dimension, since the opposition side categorized itself in ethnic terms. The opposition attempted to expand the conflict from an elite-level into a mass-level conflict, and from an internally driven into an externally driven conflict. Despite the presence of ethnic grievances and some other conflictual factors, the strategy of the Mari elite directed at ethnic mobilization and conflict escalation failed. Authoritarian conflict management provoked its escalation but also provided means, including criminal ones, to suppress minority activism. 


\section{Theoretical perspectives on conflict and diversity management}

It has been noted that since the end of Cold War, conflicts rarely occur between states but rather between different groups within states (Wolff 2007: 10-12). Ethnicity might serve as a ground for conflicts. As other social conflicts, ethnic conflict is the struggle for power in society. Ethnic conflicts are often associated primarily with armed conflicts between ethnic groups. During the disintegration of the Union of Soviet Socialist Republics (USSR), several violent ethnic conflicts emerged. For example, the conflict in Chechnya escalated into an ethnic war. Yet, conflicts differ in terms of their intensity. Not all conflicts include outright ethnic violence. Scholars usually agree that neither ethnicity nor nationalism in itself causes ethnic conflict (see Wolff 2007: 1-5). Cases of low-intensity confrontation are often described as ethnopolitical conflicts.

In ethnopolitical conflicts, "groups define themselves using ethnic criteria and make claims on behalf of their collective interests against the state, or against other political actors" (Gurr 1994). As implied in this definition, the conflicts can be between an ethnic group and the state or between two ethnic groups. An ethnopolitical conflict combines features of a political conflict and of an ethnic one. In terms of its origin, it can be a political conflict that acquires an ethnic dimension or an ethnic conflict that spreads to the political sphere. Usually it is a conflict between political actors over access to political resources, but at least one of the sides of the conflict categorizes itself in ethnic terms.

Structural models of conflict often distinguish the conflict situation, its scope and context. The conflict situation includes the actors, their interactions and the issues at stake. The sides, causes and trajectories of conflicts vary depending on the type of ethnic groups involved. Barbara Harff and Ted Gurr consider several types of ethnic groups: ethno-nationalist groups, indigenous peoples, ethnoclasses, communal contenders and dominant minorities (Harff \& Gurr 2004). At the domestic level, the sides of a conflict usually include such political actors as political institutions, political parties and interest groups or social movements; at the individual level, these are political elites and leaders (see Jesse \& Williams 2010, chapter 2).

Dynamic models of conflict describe its development through different stages. A typical model includes the stages (phases) from the absence of conflict to a latent conflict, the emergence of conflict, its escalation, stalemate, de-escalation and settlement/resolution (see Brahm 2003). Certain 
factors can exacerbate or restrain conflicts at their different phases (see Miall 2004: 74-75). Scholars distinguish underlying and proximate causes of conflict that amount, accordingly, to permissive conditions and triggers of conflict, and characterize its latent phase and its emergence. A lack of respective factors or the presence of mirror factors emerge as conflict preventers.

Michael E. Brown suggested a classification of factors that contribute to the emergence of internal conflicts (see Brown 2001). Underlying causes include structural, political, socio-economic and cultural factors; conflicts are triggered by elite-level or mass-level factors and by internal or external developments. Brown's classification is laid down into the structure of this paper. The second part of the paper will outline the developments at the federal level by analyzing the main structural factors. The third part on the structural characteristics of the conflict in Mari El will first explore the presence of socio-economic and cultural factors and then continue with political factors. The fourth part on the dynamics of the conflict will assess its proximate causes and development. Harris and Reilly (1998: 46-47) suggested a model of the conflict escalation expressed in the behavior of the conflict sides. Their model adds nuances to the conflict development from its emergence to its escalation, and it is used as the framework for the analysis. This model distinguishes the following stages listed in rising order of escalation: discussion, polarization, segregation and destruction. In the analysis, the term 'escalation' is used narrowly to refer specifically to the involvement of the third parties in the conflict (see Jesse \& Williams 2010).

The models typically mark conflict management as the last stage. This study will also explore the response of the Russian federal and regional authorities to the conflict. The state's choice of an approach directed at conflict prevention or resolution largely determines the configuration of causes and preventers. Democratic states primarily use integrationist and accommodationist approaches to diversity. Power sharing and federalism are among the most widespread accommodationist devices. Authoritarian regimes often rely on integrationist and assimilationist approaches. Their devices often include ethnic domination, wherein the dominant group's elite monopolizes the power positions and co-opts the subordinate group's members to conceal its dominance and ensure control over the subordinate group (for details, see McGarry et al. 2008). Russia's approach to diversity management will be addressed in the next part. 


\section{Russia's authoritarian tendencies and regional politics}

Michael E. Brown (2001) lists weak state structures, intra-state security concerns and ethnic geography as the main structural factors of conflict. After the collapse of the USSR, ethnic Russians constituted an 80\% majority of the country's population and were dominant everywhere except in some regions with territorially concentrated ethnic groups. Despite the fears that Russia could repeat the fate of the USSR, the state preserved its integrity and monopoly of violence except for in Chechnya, which was perceived as the major security threat (see Snetkov 2015). The major cost of the success in rebuilding the state was the failure of democratization.

On the wave of democratic transition of the early 1990s, Russia's 'multinational people' was recognized as the source of state power, and ethnic diversity was recognized. The system of ethnic federalism became the main device of diversity management in Russia. Federalism is a territorial solution that combines elements of shared-rule and regional self-rule. Powers can be shared both at the federal level and between the federal center and the regions. In Russia, the constitution has not established power sharing at the level of the federal government, but powers were shared between the federal center and regions. Ethnic regions, republics and autonomous regions were 'titled' after their autochthonous groups and functioned as a form of their self-governance. The status of republics and autonomous districts was an element of the accommodationist approach towards their 'titular' groups. At the same time, the Russian constitution established equal status of regions and only two additional rights of ethnic republics were recognized: the right to have their own constitutions and state languages. Thus, the link between ethnicity and territory remained largely symbolic but signified the perception of ethnic regions as a form of the self-rule of their titular groups (see Zamyatin 2016a: 30-33).

Democratic transition in Russia had an uneven path. The constitution approved new democratic political institutions that largely contributed to the stabilization of the political situation in the country. At the same time, an uncompromised win of president Yeltsin in the conflict with the Russian parliament in October 1993 led to the adoption of the constitution that implanted the seeds of authoritarianism by giving him virtually unrestrained power (see Gel'man 2015: 54-56). The republics copied the model of the political system with the strong presidency. With that, the major trends of regional politics became the localization of politics and the mo- 
nopolization of control over key resources mainly in the hands of regional chief executives, that is, presidents of republics and regional governors (see Gel'man 2010: 1-2).

In fact, since the late 1990 os the first sub-state authoritarian regimes were already being established in some ethnic republics of Russia. Consolidating the regimes, regional chief executives managed to maintain their grip on power, for example, by ignoring the separation of powers between regional authorities and local self-government (Alexander 2004: 250-251). Chief executives typically became dominant actors in regional politics, either by compromise or by force. Compromise gave ground to power sharing, when elites of the major ethnic groups in ethnic republics were typically included in the winning coalitions. Alternatively, the dominant actor in a forcible pursuit of the 'winner takes all' strategy removed other actors from power positions. In ethnic republics, the marginalization of rival elite segments typically amounted to domination of the strongest group (see Zamyatin 2016b).

After Vladimir Putin became Russia's prime minister in August 1999, he embarked on a course directed at rebuilding the strong state and establishing state control over (1) central political institutions and (2) regions, (3) business and (4) mass media. Accordingly, actions were taken against the opposition and regional leaders, oligarchs and mass media magnates. Among the first actions, the new Russian government launched the second Chechen war. After Putin's victory in the March 2000 presidential elections, major institutional changes of 2003-2005 were introduced that ensured the monopolist dominance of the ruling group. The political regime evolved from that of 'sovereign democracy' into a regime coined 'electoral authoritarianism'. The latter term means that elections were preserved but did not result in the change of leadership due to 'an uneven playing field' and, instead, served to legitimize the political monopoly of the ruling group (see Gel'man 2015: 7).

Decentralization of the 1990 s and strong regions were perceived as being among the main manifestations of a weak state. Accordingly, the recentralization of power conceptualized as building of the 'power vertical' became the strategy. The building of a top-down governing system was not a one-time action but a protracted systemic effort aimed at the de-federalization and de-ethnicization of politics (see Zamyatin 2016a: 36-38). In May 2000, seven federal districts were created above the level of the constituent subjects of the federation. A campaign was initiated to 'bring re- 
gional legislations into concordance with the federal legislation', targeting the provisions on republics' sovereignty. Political parties advancing ethnic and religious claims were explicitly banned by federal law. Regional political parties were ruled out by the requirement of membership from more than half of regions (see Alexander 2004). The electoral reform opened the possibility for federal parties to penetrate regional politics, and soon for United Russia to become the dominant party. After the school siege in Beslan in September 2004, an amendment to the federal law eliminated the direct elections of regional chief executives, that has been in force since January 2005. This abolishment undermined the vertical division of powers as the core principle of federalism (see Gel'man 2010: 1-2).

The recentralization undercut the regional powers but did not immediately change the constellations of political actors in regions. As long as the regional chief executives were elected until 2005, the federal center could expose its influence in some regions only indirectly, and the economic expansion of statewide businesses into regional markets preceded political subordination. Once the Kremlin succeeded in establishing control over the next region, usually though the appointment of a loyalist as its chief executive, it typically did not dismantle the regional variety of the authoritarian regime that had existed hitherto, because it saw its benefits in keeping the arrangements that provided it with electoral support. The Kremlin even allowed some heavyweight presidents of republics to stay beyond the limit of two terms in office in exchange for their consent to the abolishment of their elections. Moreover, the new presidents did not usually change the method of diversity management in republics, be it power sharing or ethnic domination, because continuity ensured the stability of ethnically divided societies (Zamyatin 2016b). In this context, the change in the method of diversity management that accompanied the establishment of control in Mari El was rather an exception.

Thus, regional politics often continued to be a significant variable for ethnic politics also after 2000, whether a republic was under an indirect influence or direct control of the center. Therefore, the contemporaneity of the authoritarian turn in Moscow and in Mari El does not suffice in itself to explain the change in ethnic politics in this republic as that imposed from the Kremlin as part of its authoritarian agenda. The impact of regional politics should also be studied (Zamyatin 2015: 385). 


\section{Structural characteristics of the conflict}

\section{I. Ethnic and social situation in Mari El}

The Mari are an ethnic group who speak a Finno-Ugric language. If measured by their geographical distribution and language retention rates, ethnic Mari are a relatively unassimilated and moderately concentrated ethnic group with their 'ethnic homeland' having the status of a constituent republic of the Russian Federation. At the same time, almost half of ethnic Mari reside in other regions, notably, in the Republic of Bashkortostan (see Lallukka 2003). Despite the overall gradual decline in the population, the ethnic composition of the population of the Mari Republic has remained stable in the post-Soviet period (see Šarov 2007: 163-164).

In 2002, out of almost 730 thousand inhabitants in the Mari Republic, about 312 thousand reported themselves as ethnic Mari, which corresponds to slightly more than half of all Mari in Russia. Among them, one in seven specified his or her identity as Hill Mari, a sub-ethnic group. In the population of the Mari Republic, ethnic Mari made up 42.9\%, ethnic Russians $47.5 \%$ and ethnic Tatars 6\%. Rural dwellers compose $39.6 \%$ of the republic's total population, while in Russia as a whole this share is around half that, with $23 \%$. Accordingly, the most important economic sectors is agriculture and forestry, although in the capital city of Yoshkar-Ola there is some military industry (see Šarov 2007: 165, 169-171). Mari El is among the more 'backward' regions of Russia in terms of economic development and standard of living, and is ultimately dependent on federal subsidies. In the late 1990s, over half of its inhabitants lived below the poverty line, which, among republics, was better only than in Dagestan, Ingushetia and Tuva (see Bahry 2002: 699).

Scholars typically distinguish between vertical and horizontal types of ethnic and social stratification, where either one group is subordinated to another or the groups form segments across social divisions (see Horowitz 1985: 24-36). Subordination manifests itself in varying access to higher education, white-collar jobs and socioeconomic inequality. In segmented societies, the ethnic identity of an individual does not correspond with his or her social status. In reality, both stratification and segmentation typically co-exist. Every group participates in different economic sectors but tends to be over- or underrepresented in high-status jobs (see Marger 2011). Overlapping social and ethnic cleavages increase the potential for conflict. 
Brown (2001) lists economic problems, discriminatory economic systems and uneven modernization as the main socio-economic factors, and cultural discrimination and ethnic mythologies as the main cultural factors of conflict.

In Russia, populations of ethnic regions represent a variety of patterns of stratification. In some republics, for example, in Tatarstan, the titular group and local Russians have roughly similar employment structures and compete for jobs. In other republics, either the titular group or ethnic Russians are overrepresented in high-status jobs. The economic collapse of the early 1990 s exposed some social problems connected to unequal economic and educational opportunities across ethnic groups. In Mari El, the social differentiation between urban and rural dwellers largely overlaps with the ethnic cleavage (see Lallukka 2003: 267-268). In 2002, 70\% of all rural dwellers were ethnic Mari and 22.8\% ethnic Russians. Sixty percent of ethnic Mari in the republic were rural dwellers and only $17 \%$ of ethnic Russians. A total of $9.5 \%$ of Mari and $18.2 \%$ of Russians had higher or postgraduate education. Thus, the local ethnic Russians are predominantly 'modernized' city-dwellers. However, Yoshkar-Ola, with its population of about 250 thousand, is a rather small city for a regional capital and lags behind the megacities of Kazan and Nizhniy Novgorod. These and other cities attract outmigration from Mari El, which is highest among ethnic Russians (see Šarov 2007: 170-173).

Still, the Mari are more of a 'traditional group' without a full-fledged social structure (see Lallukka 2003: 266-267). The Mari are disproportionately employed in agriculture, but also in construction and the service sector. Elise Giuliano evaluated that Mari El was the second from the bottom among the republics (next to Chechnya) by its ratio of ethnic division of labor (see Giuliano 2011: 77-78). One Mari for two Russians in the republic were in white-collar jobs. Less than $20 \%$ of the urban Mari were in whitecollar jobs and only about $12-13 \%$ Mari in the countryside (Drobiževa 2002: 28-29). This type of ethnic stratification gives ground for instances of prejudice and discrimination typically expressed through verbal abuse and denial of some social resources, such as equal access to education. Sociological research has found that a significant portion of respondents have experienced intolerance because of their ethnicity (see, for example, Sbornik 2005).

In Yoshkar-Ola, ethnic Mari composed less than a quarter of all inhabitants. The overall share of urban dwellers is gradually increasing but 
remains stable among the ethnic Mari, which is probably an effect of assimilation. Many among those young people of ethnic Mari origin who grow up in the urban areas often have a poor knowledge of the Mari language and mixed identities (see Šarov 2007: 163-165). A total of $84.2 \%$ of the Mari in the republic reported knowledge of the Mari language. Varying adaptation strategies of rural, first-generation and second-generation urban Mari have undermined ethnic solidarity among the Mari and contributed to the blurring of ethnic boundaries. Despite this, the segmentation between ethnic groups has remained relatively high. For example, in 2002, the share of inter-ethnic marriages was below 20\% (see Fauzer 2011).

\subsection{National movement, political elites and authorities}

Liberalization and the weakening of the Soviet political regime during perestroika led to the activation of the titular intelligentsia also in the Mari Republic. These were primarily members of the ethnic cultural elite such as writers, scholars, journalists and people in other creative professions. They started to express their concerns about language loss and assimilation and to present demands to the authorities to improve the deteriorating situation of the Mari language and culture (Lallukka 2003: 273-275). Indeed, these people initiated the popular ethnic mobilization that resulted in the emergence of a national movement, that is, 'organized endeavors to achieve all the attributes of a fully-fledged nation'. Notably, it was not a 'nationalist' but a 'national' movement, because its goal was not outright independence but greater autonomy (see Hroch 1993: 6).

According to Hroch, such movements typically evolve in stages, from the elite presenting linguistic and cultural demands to political demands and gaining popular support. Accordingly, if at the initial stage, leaders and activists of the Mari movement included mostly members of the ethnic cultural elite, then soon some members of the ethnic political elite joined, too. These were the later generations of 'national cadres' who were being trained and co-opted into the Soviet bureaucracy typically referred to as nomenklatura. Since the 1920s, cadres of 'titular nationality' were promoted under the early Soviet policy of korenizacija (indigenization) of the state apparatus in ethnic regions (see Lallukka 2003: 42-43). The latter circumstance gave the ground to characterize the Soviet practice of establishing of a new governing elite in the republics 'from above' to guide national sentiment as a separate stage (see Martin 2001: 15). 
In the early 1990s, the combination of 'bottom-up' public initiatives and the elite efforts determined the pace of mobilization (see Zamyatin 2014: 86-91). In 1990, the activities of the Mari national movement reached a new organizational level with the creation of a democratic public organization Mari Ušem in close consultation with the authorities. The key figure of this organization was Nikolaj Rybakov, head of the republic's writers union and the chair of the Supreme Council, a Soviet-style parliament. Initially, Mari Ušem declared that it would pursue cultural goals and restrained from positing political goals, which was the condition for cooperation with the authorities. Soon, this modesty led to a split in the national movement, when some of the younger and more radical activists created another national organization Kugeze Mlande, which declared political goals. A significant factor was the sub-ethnic division, wherein Hill Mari elite were overrepresented in power corridors 'at the expense' of Meadow Mari (see Lallukka 2003: 277-279; Zamyatin 2015: 364-365).

Nevertheless, the national movement became a significant regional political actor, because the republic's leadership needed it for the legitimation of its position vis-à-vis the Kremlin. Furthermore, national organizations provided support to presidential candidates and ensured the victory of Vladislav Zotin, a party functionary and an ethnic Mari candidate, in 1991. In 1991, Nikolaj Rybakov was appointed state secretary, a newly created position serving as an aid to the president in nationalities issues. In 1992, Rybakov initiated the arrangement of a Congress of the Mari People and became the head of its organizing committee. The Congress was numbered as the third, in order to emphasize its continuity with the two congresses that had taken place in 1917 and 1918. As in other republics, the idea was to publicly demonstrate popular support for the claims of national movement (for more about the representative nature of the people's congresses in Russia, see Osipov 2011). The congress was to be held every four years with the All-Mari Council Mer Kayaš acting as an executive body between congresses. The congress claimed political legitimacy to be the body of ethnic representation and advocated for the establishment of a second chamber of parliament to be elected on the principle of ethnic representation (Lallukka 2003: 281-283; Zamyatin 2015: 366).

Activities of the Mari national movement provoked a counter-mobilization of Russians in the region based on concerns about the prospects of ethnic discrimination (see Lallukka 2003: 46-47, 266, 284). Popular support in the republic for the Liberal Democratic Party of Russia (LDPR), a 
nationalist party headed by Vladimir Žirinovskij, was noticeable especially in federal elections in the 1990s. As in other former union and autonomous republics, local Russian nationalists organized themselves into a regional branch of the movement Rus'. After the Congress, a group of thirty republican parliamentarians and some $R u s^{\prime}$ activists protested against the ambitions declared at the Congress. The leaders of the Mari national movement had to apologize and to deny being nationalist (Zamyatin 2015: 366-367).

In comparison to some other republics, popular support for regional separatism and cultural nationalism in Mari El remained low (see Gorenburg 2003: 253). Despite this, ethnic mobilization in Mari El still reached the stage of a truly mass national movement, although only for a relatively short period in 1992-1993, right before and for some time after the Congress (see Lallukka 2003: 321-322). Based on media analysis, Elise Giuliano attributed the low support for the movement to the failure of national organizations to connect the problem of the disadvantaged social position of the Mari and Mari underrepresentation in high-status jobs to the goal of republican sovereignty (see Giuliano 2011: 149-150, 170). In fact, in one of its resolutions, the Congress addressed the problem of ethnic representation, but the discussion in mass media was mostly held in the Mari language. I have argued elsewhere that despite their failure to achieve their political goals, national organizations were relatively successful in mobilizing electoral support in the early 1990 s in and raising the issue of ethnic political representation in the political agenda. For example, Mari Ušem won a party-list seat in the 1993 republic's parliamentary election (see Zamyatin 2015: 361-362).

With the stabilization of the new political system, the appeal of nationalist ideology to the masses decreased. Instead, under the conditions of sever economic crisis, Mari El was counted among the regions in the 'Red Belt', with a high level of popular support for the Communists. The Communists and their allies Agrarians were the strongest regional political force. Regional democrats remained weak. At one moment, ethnic cultural elite members sought contacts with regional democrats but could not find a 'common language', because the latter opposed sovereignization. Mari Ušem and Kugeze Mlande continued to participate in elections on the particularist agenda of 'national revival' but were not successful. In 1994, a newly created political party Ušem was also not successful (see Zamyatin 2015: 367-368). At the same time, party politics was not at the core of regional political life. Most politicians were pragmatists and supported the 'party of power'. 


\subsection{Political institutions and ethnic politics}

According to Brown (2001), discriminatory political institutions, exclusionary national ideologies, divisive intergroup politics and elite politics are the main political factors leading to conflict. While the Russian political system of the 1990 os was designed to avoid systemic discrimination, it did not ensure substantial minority political participation (see Zamyatin 2015: 355-357). Since the early Soviet times, the idea about the 'equality of peoples' coincided with the de facto hierarchy of 'national-state formations'. The Mari Autonomous Region was established in 1920 as a part of the Nizhniy Novgorod Region within the Russian Soviet Federative Socialist Republic (RSFSR). In 1936, it was upgraded and re-established as the Mari Autonomous Soviet Socialist Republic of the RSFSR (see Sanukov 2005). However, since the late 1930 s and throughout the Soviet period, behind the façade of ethnic federalism, the USSR functioned as a unitary state, which provoked aggravation of national resentment and inter-ethnic tensions (see Zamyatin 2016a: 25-26).

In 1990, the Mari Republic passed the declaration of state sovereignty, which upgraded its political status to that of the 'sovereign state created on the basis of the exercise of the Mari nation of its inalienable right to national self-determination' (p. 1, Declaration of State Sovereignty of the Mari SSR, 22 October 1990). In this context, the Mari could be categorized as an 'ethno-nationalist' group with a historical tradition of territorial autonomy according to Harff and Gurr's classification. It should be noted that in the Soviet discourse, the terms 'nation' and 'national' had not corresponded to the state as a whole but to sub-state units. Thus, the act of sovereignization had not sought outright independence but an upgrade in the republic's political status. Moreover, the status of 'nation' assumes the existence of an autonomous political organization, but the national statehood of the republic envisaged in the sovereignty declaration remained a vision rather than a reality (see Lallukka 2003: 33-35).

While a joint interest of regional elites in greater self-government of the republic enhanced its state-building, the pursuit of nation-building was a matter of controversy concerning whether its driver should be ethnic or civic nationalism. The ethno-nationalist project was doomed to fail given the heterogeneous ethnic makeup of the republic's population and its dependence on the federal center (see Lallukka 2003: 44-45). Thus, as in all other former autonomies of Russia, the nation-state building in Mari 
El was based on the civic-nation model. Both the sovereignty declaration and the 1995 constitution of the Mari Republic recognized the bearer of sovereignty to be 'the people of the republic consisting of citizens of all nationalities'. The constitution had neither mentioned the Congress of the Mari People nor created other formal mechanisms to ensure ethnic political participation. In the Russian legal space, the congress could legally function only as a public association and could participate in this capacity in consultative bodies (see Osipov 2011: 8-9).

In general, the established political system maintained inclusive political institutions based on the idea of a civic nation. The republic had to ensure some instances of preferential treatment of the titular group. The sovereignty declaration and the constitution established Mari and Russian as the state languages of the republic. The education law was passed already in 1992 and the language law in 1995, and these were stronger than the respective laws in many other republics in terms of the promotion of the titular language and culture. The Mari language not only continued to function as the medium of instruction and be taught as a native language but also had to be taught to all students irrespective of their ethnic identity (see Zamyatin 2013: 133-134).

The early 1990 s were characterized by an upsurge in social movements. Despite the ethnic mobilization, intergroup politics had not reached the level of confrontation and mostly remained peaceful. Contrary to some accounts, there were ethnic demonstrations and other instances of mass protests, but no cases of ethnic violence were reported, (see Giuliano 2011: 36; Zamyatin 2015: 365). Throughout the 199os, the elite segments representing the major ethnic groups, Russians and Mari, sustained proportional participation (Zamyatin 2015: 380-381). This was possible because the regional elite remained ideologically unified due to its common origin in the nomenklatura and its joint interests vis-a-vis the federal center. The continuity of political elites ensured a level of consensus regarding the ethnic issues as well.

Since the mid-1990s, the decrease in mass political participation has been accompanied by the decline in political salience of ethnicity for the masses in most republics. Ethnic politics has returned to its regular mode of political bargaining. Titular ethnic representation in Mari El somewhat decreased after the 1996 parliamentary elections, but the role of regional legislatures as power centers also decreased. Post-Soviet discrediting of ideology contributed to the weakness of political parties in regions and the 
prevalence of clientelism. Outside party politics, ethnic issues still found their solutions in elite politics, which often depended on the position of the republic's leader. As in Russia as a whole, either 'parochial' or 'subject' types of political culture continued to prevail over 'participatory' culture in the republic, which ensured the primacy of elite political cultural and popular support for the "party of power". Informal power-sharing arrangements ensured an ethnic balance of power in government (Zamyatin 2015: 385).

Power sharing was sustained through the interaction of the authorities and interest groups, which was organized on the model of state corporatism. In the corporate political culture, interest groups were represented by national organizations that were dependent on authorities. In 1995, the authorities forced a more radical organization Kugeze Mlande to stop its activities. Accordingly, Mari Ušem and Mer Kayaš remained the peak organizations. In exchange for restraint from political ambitions, they received financial state support for their activities and could to a certain extent participate in the formation of nationalities policy and language policy, for example, receiving a seat at the table in drafting the constitution and the language law (Zamyatin 2015: 369-370).

This is not to say that there were no conflicts. A political conflict emerged in connection to the presidential election in 1996 that had an ethnic undertone to it. Before the election, the Fourth Congress of the Mari People was held, supporting the candidacy of the president in office. President Zotin attempted to enforce the provision on language requirements for presidential candidates in order to ensure his re-election. After federal interference, the attempt failed and Zotin lost already in the first round (Zamyatin 2015: 370).

Vjačeslav Kislicyn was elected the new president in the second round. Kislicyn, as a former kolkhoz chief and later the head of a rural district administration, was popular in all rural districts. He joined the Communists in 1995. His main rival, Leonid Markelov, won only in Yoshkar-Ola. Unlike the local Kislicyn, Markelov was a native Muscovite, who had receive a work assignment in the Yoshkar-Ola Military Procuracy in 1986 and in the new times worked as a barrister. Markelov was the head of the regional branch of the LDPR and became a deputy of the State Duma, the lower chamber of the Russian parliament, from this party in 1995-1999. During his presidential campaign, he publicly promised to "protect the interests of the ethnic Russians" and proposed repeatedly his solution of the issue of 
ethnicity that the republic "should simply be one of Russia's many regions" (Alexander 2004: 243-244, Zamyatin 2015: 369-370).

The confrontation during the 1996 presidential election campaign remained an institutional conflict that found intra-elite settlement in a compromise. The substitution in the election of the ethnic Mari Zotin with the ethnic Russian Kislicyn had not split the elite. Further, the establishment of a monocentrist and corrupt regime has not significantly changed the ethnic balance of power. After his coming to power, Kislicyn left the ethnic aspects of the power-sharing deal untouched (see Lallukka 2003: 305-306; Zamyatin 2015: 371). The situation of a dual balance of power in the region sustained regional power-sharing but was prone to confrontation because of the high incentive for the 'winner takes all' strategy (see Lijphart 1977: 55-61). In the latter case, the shift to ethnic domination could have been expected, as happened in Mari El (Zamyatin 2015: 385).

\subsection{The authoritarian turn and the emergence of conflict situations}

Before the 2000 presidential election, the Fifth Congress of the Mari People was held, in which Viktor Nikolaev was elected to be the leader of Mer Kayaš. In the election, the congress supported the candidacy of Ivan Teterin, an ethnic Mari and an army officer. The federal center, personified by Sergei Kirienko, presidential representative in the Volga Federal District, backed the republic's interior minister Anatolii Ivanov. Neither made it to the second round (see Lallukka 2003: 312-313; Zamyatin 2015: 374). In December 2000, Leonid Markelov was elected president of the Republic of Mari El in the second round. Markelov won against the incumbent president Vjačeslav Kislicyn, with active support of Kirienko, although for the latter his candidacy was the forced choice (see Belokurova \& Denisova 2003: 82-86; Alexander 2004: 243-244). Markelov started his presidency with the pursuit of the monopolization of regional power and the establishment of the regional variety of an authoritarian regime. As at the federal level, the power grab included establishing control over (1) the republic's political institutions and (2) lower levels of administration, (3) businesses and (4) mass media.

First, as has been typical also for other regions, the new leader affirmed his power by firing employees of the previous administration and appointing his loyalists to public offices (Belokurova \& Denisova 2003: 87-88). In Mari El, the dismissals disproportionally targeted members of the titular 
elite. A diachronic study on the dynamics of ethnic political participation in Mari El found that the arrival of the new ruling group in 2000 led to a significant decrease in the share of officials of ethnic Mari origin (see Zamyatin 2015). In fact, a comparative study of ethnic political participation across the republics demonstrated that since 2000, Mari El has become the republic with the most disproportional ethnic representation, which has amounted to ethnic domination (see Zamyatin 2016b).

Second, in the same way as the Kremlin ignored the vertical separation of power in its recentralization efforts, regional heads subordinated municipalities. Local self-government is not supposed to be part of the state apparatus and municipal deputies must be elected directly by the population, but the 2003 municipal reform in Russia resulted in municipalities being turned into another branch of state power. In Mari El, first the redistribution of financial resources from municipal budgets to the republican budget increased the dependence of municipalities, and especially of the capital city (Belokurova \& Denisova 2003: 90-91). In 2004, Mari El became one of the regions where the reformed municipal assemblies began appointing the city mayor and the heads of municipalities, which made these public servants more controllable by the authorities (see Gel'man 2010: 10-11).

Third, Markelov, with his team of 'outsiders', started an extensive process of property redistribution. The president initiated forced bankruptcy of three hundred public and private enterprises, or about $40 \%$ of all the enterprises in the republic (Doklad 2002, section 4). The goal of 'improving the investment climate' was, of course, to fill the budget. However, the result was that Moscow-based financial industrial groups, through various corruption schemes, took over the republic's assets. According to the observers, a covert goal of bankruptcy was the removal of those directors of enterprises who were supporters of the Communist party and the previous president, many of whom now faced criminal charges (Belokurova \& Denisova 2003: 90).

Fourth, Markelov's team cracked down on mass media. Dmitrij Frolov, head of the presidential administration, allegedly coordinated the takeover of mass media. Emblematically, by the first decree, Markelov appointed his crony Vasilij Pančenko as editor-in-chief of the main official newspaper of the republic, Marijskaja Pravda (see Belokurova \& Denisova 2003: 88). Within a couple of years, the authorities had succeeded in establishing control over the main republican mass media. Some private independent news- 
papers continued to function but were forced out from the republic's publishing houses and moved their printing to the neighboring regions (Šarov 2005: 206). In 2004, United Russia coordinated efforts to reach an unofficial agreement between the authorities of the regions in the Volga Federal District not to print each other's independent newspapers. This arrangement eliminated the possibility for printing fifteen newspapers from Mari El in the neighboring Kirov Region and elsewhere (see Nyman 2006: 36 ).

An authoritarian regime is characterized not only by its goal of power monopolization but also by the authoritarian methods employed. According to the oppositional mass media, the combination of the use of selective and arbitrary law enforcement with the alleged employment of criminal methods became a feature of the new autocratic leadership style in Mari El. In the late 1980 s, Markelov had allegedly built up contacts in the criminal underworld while working for law enforcement. Capitalizing on acquaintances in the early 1990s, he apparently pursued some shady business activities and a criminal case was initiated against him, although it should be added that the latter was a widespread manner of dealing with political opponents. Being a member of the LDPR, he also is said to have established contacts among the ethnic Russian nationalists. Many journalists believed that since becoming president in the 2000s, he has used these contacts to silence and neutralize opponents (Doklad 2004: 6-9; Doklad 2005: 3-5).

Inevitably, the power grab provoked conflicts in all the relevant spheres. First, Markelov as the regional chief official could dismiss public officials and civil servants without major obstacles, but the gradually developing conflict with the opposition proved also the most durable, and its dynamics will be studied in the rest of the paper. Second, encounters with local self-government provoked immediate and open institutional conflicts with some heads of municipalities, who acted independently and hampered the president's plans for municipal property redistribution. The resolution of these conflicts is a good illustration of the new president's authoritarian methods. Markelov not only assured the dismissal of the mayor of Volžsk and the head of the Zvenigovo rural district, but also instigated criminal investigations against them. In 2002, the head of the Zvenigovo district, Mihail Žerebcov, was beaten up, an attack that went unreported in mass media (Doklad 2002, sections 1 and 4). The mayor of Volžsk, Nikolaj Svistunov, was put in jail for alleged financial infringements (Belokurova \& Denisova 2003: 90-91; Doklad 2006: 151-152). Third, similar methods were used in the business world. 
Finally, journalists allegedly became a special target. Several journalists were killed: vice-editor-in-chief of the opposition newspaper Dobrye Sosedi Aleksandr Babajkin in November 2001, deputy head of the department of the Publishing House Periodika Mari El Leonid Plotnikov in October 2002 and journalist of a rural district newspaper Aleksei Bahtin in October 2003. Among numerous other crimes, in March 2002, an armed assault was committed on Vladimir Malcev, editor-in-chief of Dobrye Sosedi and former long-time chief editor of Marijskaja Pravda, and two days later, the door to his apartment was set on fire. After investigations, law enforcement agencies had not found the perpetrators, but claimed that the crimes were not linked to the journalists' professional activities (see Otčët 2002; Nyman 2006: 36-37). The amalgamation of corrupt law enforcement and the underworld ensured that the perpetrators typically were not found. No verifiable data is available to indicate that the crimes against journalists and opposition leaders were politically motivated, but the pattern in the manner of offences is evident. Numerous attacks have been well documented and described in regional human rights reports.

\section{Dynamics of the conflict}

\section{I. From a latent conflict to the outburst of the conflict}

From discussion to polarization: problems of ethnic participation, language teaching and the freedom of press (200I)

According to Brown (2001), the proximate causes of conflict can include elite-level or mass-level factors and internal or external developments. Three typical variations of internal elite conflicts include ideological struggles, criminal assaults against the state sovereignty and power struggles. Power struggles are the most common variation and were also present in Mari El. As in Russia itself, the building-up of an authoritarian regime in Mari El in the early 2000 s was a gradual process. The deterioration of the positions of old regional elites was protracted in time. Those still in power positions had no interests to back those already fired. However, at some point the accumulated frustration with Markelov's regime also led to the outburst of a conflict in ethnic relations.

The perceptions of deprivation started to accumulate among the titular elite with the formation of the new government, which was mostly made 
up of newcomers, in February 2001. Even if the titular elite had supported Markelov's rivals in the presidential elections, ethnic Mari politicians still hoped to receive some government positions based on the model of state corporatism valid hitherto. Initially, the new president maintained an element of ethnic parity only at the level of the first vice-premiers and vicepremiers. Ethnic Mari politicians signaled their dissatisfaction with the division of government portfolios. However, the ministers of culture and minister of agriculture soon remained the only ethnic Mari in government. Notably, Rimma Kataeva left the post of the minister of education. A remarkable breach of parity was the approval of two Muscovites as the republic's representatives to the Federation Council, the upper chamber of the Russian parliament (Belokurova \& Denisova 2003: 88).

Soon Markelov began to displace local politicians and bureaucrats at the lower echelons of government, in municipalities and all the way down to public institutions with his cronies, many of whom he knew from his days in Moscow. The new appointments in government not only touched on the interests of old elites in the economic sphere but also in the social and cultural sphere where hitherto national intelligentsia had traditionally been overrepresented also in senior positions. In 2001, director of the Publishing House Periodika Mari El Aleksandr Samsonkin, director of the Mari Publishing House Albertina Aptullina and director of the Printing and Publishing Works Aleksandr Solovjëv were fired, among others (Otčët 2002; Belokurova \& Denisova 2003: 89).

The consolidation of the regional political regime through authoritarian methods coincided with the symbolic redistribution of power between the federal center and the region. In the end of 2000, the sovereignty declaration was made void and the provision on sovereignty was excluded from the constitution as part of the enforcement of the supremacy of the federal legislation. The process continued in 2001, when the bilateral powersharing treaty between the federal center and the republic's authorities was renounced. This process affected the social and cultural sphere. In January 2001, the draft to revise the 1995 language law prepared in the Public Procurator's Offices of the Republic was made public (Belokurova \& Denisova 2003: 86-87). In February, the new minister of education, an ethnic Russian, argued in Marijskaja Pravda against the compulsory teaching of the Mari language (see Lallukka 2003: 316).

The combination of dissatisfaction with political underrepresentation and the threat to the position of the Mari language and culture in the pub- 
lic sphere created the conflict situation. Members of ethnic cultural elites expressed their concerns about the deteriorating position of the titular language in school. Mari Ušem and Mer Kayaš appealed to the president and proposed a new draft for the language law. Some seminars were arranged on the issue of languages in education, in hopes of reaching a compromise. Nevertheless, in March 2001, the old 1992 education law was abrogated. The minister of education abolished the department of national education in the ministry of education. The language law was revised based on the Procurator's draft later in September 2001. In effect, the Mari language ceased to be used as the medium of instruction and taught as a compulsory study subject as a state language of the republic, and the amount of teaching and the number of students having access to its study decreased dramatically through enforcement of the free choice of language learning (see Zamyatin 2013: 133-134). Further steps included the abolishment of the republic's terminological-orthographic commission, the language board for the Mari language. Publishing of books in Mari practically stopped (Doklad 2002, section 5).

After months of fruitless debates behind the scenes, some ethnic Mari politicians lost hope of achieving a settlement and started to criticize the president's nationalities policy openly in independent media. In doing this, the politicians categorized themselves as the 'leaders of the national movement', inter alia, because they acted in the name of Mer Kajaš, the body of ethnic representation, and Mari Ušem, an organization with one and a half thousand registered members. The government responded with its own media campaign that began on 22 February 2001 after the publication of an article in Marijskaja Pravda by its chief editor that portrayed the opponents as 'nationalists' and a marginal group, and contrasted them with loyalists. Simultaneously, the crackdown on the freedom of speech strived to close down the channels of criticism, for example, suppressing such opposition newspapers as Kudo+Kodu. In mutual public accusations, the parties distanced themselves and turned away from one another. Thus, the confrontation reached the stage of polarization.

From polarization to segregation: threats and protests (2002-2004)

In December 2001, the main Finnish newspaper Helsingin Sanomat began publishing a series of critical articles written by Mika Parkkonen, its Finnish correspondent in Russia, about the crackdown on the free press and 
the persecutions of the opposition in Mari El (Mika Parkkonen, Helsingin Sanomat, 17 December 2001). Parkkonen's visit to Mari El earlier that year also included an interview with president Markelov. The first publications coincided with the government decree on the merger of the Šketan Mari National Theater and the Theater for Young Audience. The covert goal of the merger was to get rid of ethnic leaders and activists employed in the theatres. Among others, director of the Šketan Theater Viktor Nikolaev was fired and artistic director Vasilij Pekteev was forced out (see Nyman 2006: 44).

The planned merger triggered the next circle of political confrontations. On 5 February 2002 on its plenum, Mer Kayaš appealed to president Markelov to stop the merger of the theatres and published open letters to president Putin, presidential envoy Kirienko and the General Procurator's Office of Russia. The decision was made to hold an extraordinary Sixth Congress of the Mari People. On 22 February, Mari Ušem arranged a rally in co-operation with Mer Kayaš to protest against the merger of Marilanguage theaters, as well as the authoritarian tendencies in general. The rally ended up being the first mass event attended not only by ethnic activists but also by the wider public. Between six hundred and one thousand people attended the rally, according to the official data and the organizers. Notably, ethnic activists began to categorize themselves not only in ethnic terms but as the 'political opposition' (see Lallukka 2003: 318-319).

The republic's authorities largely ignored the Congress, but a few days before its beginning. Its leader Viktor Nikolaev was beaten up and got into a hospital (he was beaten up for the second time in October 2002). Instead, the tactics of the authorities was to activate a pro-government NGO, Mari National Congress, in order to have a pocket organization that would officially represent the Mari (see Lallukka 2003: 317-318). In fact, in an attempt to turn the conflict from an 'inter-ethnic' into an 'intra-ethnic' confrontation, the authorities employed similar tactics to those used in Chechnya. If the first Chechen war became known as the war between Russians and Chechens, then during the second Chechen, war, which started in 2001, the Kremlin employed a policy of its Chechenization. After a constitutional referendum and elections fabricated by the Russian authorities, newly loyal Chechens headed by Ahmad Kadyrov began to fight against other Chechen insurgents (see Snetkov 2015: 81).

Despite the obstacles, the preparations for the extraordinary congress continued. On the day before the congress, Markelov initiated a meeting 
with Nikolaev. At the meeting, Markelov demanded that the congress not be held and made some promises but did not agree to discuss them immediately. As the sides did not trust each other, the conversation did not result in an agreement. The congress took place on 26 April 2002. In its resolution, the congress demanded the resignation of Markelov (see Lallukka 2003: 318-319). Thus, the conflict entered the stage of segregation, when the parties stopped communicating with one another.

In March 2004, the Seventh Congress of the Mari People was held without open confrontation. Greetings were announced from president Markelov. In its turn, the congress restrained from passing a resolution against the president. Still, the resolution criticized his nationalities policy and especially cadre policy that was said to ignore the national specifics of the republic. The resolution also included also a clause on the need to propose joint action plans to the government and to participate in their implementation. Vladimir Kozlov was elected the next leader of Mer Kayaš. Kozlov (a.k.a. Laid Šemier) worked as director of the museum center named after the Mari writer Valentin Kolumb and also as editor-in-chief of the Finno-Ugric newspaper Kudo+Kodu. Despite the calls for cooperation with authorities, the position of the national movement leadership towards president remained irreconcilable (Šarov 2005: 205-206). Its leaders were determined to support an ethnic Mari presidential candidate. The election was viewed as the crucial opportunity to get out of the stalemate, wherein the victory of one side was perceived as the defeat of the other side (Zamyatin 2015: 375-376).

\section{From segregation to destruction: Incidents of violence (2005)}

Despite the abolition of elections of regional chief executives, the elections that were planned earlier were held. On 19 December 2004, after a dirty electoral campaign, Markelov received more than half of all votes in the first round and was elected president for the second term. The national movement and other oppositional forces formed a coalition that supported his main contender Mihail Dolgov, an ethnic Mari. Dolgov came in second with $18.7 \%$ of the vote. The same day, an unsanctioned picket of about thirty people gathered in front of the government building, known as the 'Grey House', to protest against the election results. Among the slogans on the placards were 'Putin! Remove Markelov!' (Šarov 2005: 203-204). A few still active oppositional mass media reported gross mas- 
sive violations of electoral rules. The evidence of electoral fraud was presented, for example, in an allegation to the republic's Supreme Court by a member of the republic's Central Electoral Commission in a consultative capacity who demanded the abolishment of the election results (see the text in Doklad 2004: 19-22).

The leaders of the national movement decided to organize another extraordinary congress of the Mari people in order to assess the electoral falsification, violations and anti-Mari rhetoric of Markelov and his confidants. However, in the morning on 23 December, the congress was held not in the 3oth Victory Anniversary Palace of Culture as planned, but on the street in the cold in front of the building. Delegates could not enter the palace, because its director disappeared despite the previous agreement. According to the organizers, the delegates numbered three hundred, while in some other sources it was claimed that there was only half a hundred. The forum challenged the legitimacy of the president and passed resolutions with appeals to president Putin, Finno-Ugric peoples of the world and the international community (see Sharov 2005: 203-204).

On 7 January 2005, Elena Rogačova, a journalist who a week prior had started to work for the Moscow bureau of Radio Liberty, was beaten, constituting yet another crime committed against journalists. Simultaneously with the presidential inauguration on 15 January 2005, the opposition arranged a non-sanctioned rally of the activists of the Mari national organizations. Some sources reported that the rally was attended by several hundred who protested against the nationalities policy in the region. The police claimed that there were only a few dozen participants at the picket. The police pushed away the meeting and detained some protesters, including its initiator, Vladimir Kozlov (see Šarov 2005: 203-204).

In the morning on 4 February, Vladimir Kozlov, the leader of Mer Kajaš was attacked and severely beaten on the street on the way to his workplace in the House of Press, where he worked for the newspaper. That day, he was planning to go to a village where he knew chiefs of municipal enterprises had been fired en masse after they did not support the president in office in the elections (see Doklad 2006: 155). Allegedly, he was beaten because he supported an opposition candidate in the elections and organized a protest at the time of the presidential inauguration. In response to an international outcry, the officials refused to connect the attack to the political activities of the victim, claiming a criminal background instead. However, the timing and place of the crime, which was committed at ten 
o'clock in the morning in the public place near the House of Press situated close to the city center, does not support their allegation. The perpetrators were never identified, but many observers shared the view that the crime was politically motivated (Nyman 2006: 52-53).

On 27 May 2005, after a concert arranged in Yoshkar-Ola by the Association of the Fellow Countrymen from the Morki rural district, skinheads who 'did not like the songs performed in the Mari language' beat an artist and the director of the Morki district radio station. Another group of skinheads, consisting of about thirty individuals, attacked the participants and organizers of the concert. Around ten people suffered injuries (see Doklad 2006: 155). Reportedly, the perpetrators were members of an ultranationalist organization, Russian National Unity, who allegedly were acting on order of the head of the presidential administration, Dmitrij Frolov (Nyman 2006: 53). By that time, at least ten facts of persecutions of leaders and activists of national organizations had been reported (Doklad 2006: 155).

\subsection{Escalation of the conflict}

From a public initiative to a new dimension in international relations: International Criticism (2005)

By that year, authoritarian regimes had become the pattern in Russian regions. Violent attacks against opposition leaders and partisans of defeated candidates in the aftermath of the elections would not have come as a surprise to anybody. They would have become the next ordinary news story in a series of events in dirty Russian regional politics and would have gone largely unnoticed by a wider public if it were not for the ethnic specifics of the region. The latter was the reason the events occurred in the focal point of international attention.

The channel that enabled the dissemination of information about the conflict was cross-border Finno-Ugric co-operation. It is built on the assumed ethnic kinship of the peoples speaking Finno-Ugric languages and is a multifold endeavor that includes academic, political, cultural and youth contacts between activists from Estonia, Finland, Hungary and the Finno-Ugric regions of the Russian Federation. Politicians from Estonia, Finland and Hungary have occasionally used this platform at the European level as a channel for criticism of Russia's nationalities policy. 
Among other initiatives, in January 2003, the problems with the freedom of press in Mari El were discussed at hearings in the Committee on Culture, Science and Education of the Parliamentary Assembly of the Council of Europe (PACE) (see Doklad 2003, section 2). The Mari delegation to the Fourth World Congress of the Finno-Ugric Peoples held in Tallinn, Estonia, in August 2004 headed by Vladimir Kozlov used the opportunity to express their frustration with the policies of their titular republic's authorities. Based on the conclusions reached at the congress, the Estonian delegation to the PACE initiated in October 2004 a motion to draw up a report on the situation of Finno-Ugric peoples in Russia (Nyman 2006: 7).

On 7 February 2005, on the third day after Kozlov's beating, the Council of the Mari El Association of Fellow Countrymen in Moscow passed an address to the international community, the International Committee of Finno-Ugric Peoples and regional public associations, urging them to express their support for the Mari people in Mari El (see the text in Doklad 2004: 10-11).

As a reaction to the address, two dozen prominent public figures, academics and some former and acting politicians, mostly from Estonia, Finland and Hungary, signed a petition written by Tytti Isohookana-Asunmaa and Kyösti Julku. At top of the list was the name of Paul Goble, a former advisor to the U.S. Department of State, probably to make the document look more international and weighty. The document demanded an investigation into the crime against Kozlov. On 22 February, 'The Appeal on Behalf of the Mari People' was published in the Finnish and Estonian main newspapers, Helsingin Sanomat and Eesti Päevaleht, and was made available for signatures on the internet. During the two months that the appeal was online, it gathered about eleven thousand signatures. Criticism focused on the breaches of human rights, namely of the freedom of expression, personal liberties and political freedoms (Nyman 2006: 36-37).

In a cascade effect, the petition was followed in spring 2005 by a great number of publications in the Finnish, Estonian, Russian and international mass media, statements from politicians, state authorities, international organizations, etc. Support for the Mari was expressed, among others, by the International Helsinki Federation of Human Rights, the Federal Union of European Nationalities and the Unrepresented Nations and Peoples Organisation (Doklad 2006: 155).

The unfolding of the events around the conflict does not suggest that international criticism was the result of a pre-planned set of activities by 
state actors. Instead, one could see how information about the events was disseminated through ever-wider social communication networks (another paper is forthcoming with a discourse analysis of the mass media coverage of the events). Nevertheless, the public initiative caught the attention of politicians, after which the topic became another dimension of international relations.

In March 2005, the PACE Committee on Culture, Science and Education met to discuss the situation of the Mari in Russia and requested that a member of the Estonian delegation to the PACE Katrin Saks prepare a report about the situation of the Finno-Ugric peoples in Russia. In the following months, Katrin Saks, the former Estonian minister for population affairs with the mandate over minority issues, visited some Finno-Ugric regions of Russia. In April 2005, the European Parliament passed an action plan with regard to the Finno-Ugric peoples of Russia. In May 2005, diplomatic efforts culminated in the European Parliament unanimously passing a resolution 'Violations of Human Rights and Democracy in the Republic of Mari El in the Russian Federation' that, inter alia, cited the incidents of violence against ethnic leaders and journalists discussed above (12 May 2005) (Doklad 2006: 155).

\subsection{Conflict management under authoritarian rule}

\section{Response of russian authorities to international criticism}

The international context was that the timing of the conflict in Mari El coincided with the Orange Revolution in Ukraine, which followed the authorities' attempt to rig the presidential elections in December 2004. In Russia, the Orange Revolution was interpreted as a conspiracy steered by the CIA (see Umland 2013). This perceived threat was among the major drivers for the turn in Russian foreign policy towards isolationism that was visible by autumn 2005. For Moscow, the international criticism of the situation in Mari El seemed unprovoked and the problems fabricated, thus, part of the conspiracy. The timing of criticism induced its perception and representation as an episode in concerted Western efforts to export a color revolution to Russia. Evidence such as the signature of an American under the Appeal on Behalf of the Mari People was not hard to find (another paper is forthcoming on the place of the conflict in Mari El in international relations). 
A week after the adoption of the resolution of the European parliament, the Russian Foreign Ministry assessed its claims as misleading and interpreted the goal of its approval as an attempt 'to divert the attention of the international community from the adverse situation with human rights, first of all, of the Russian-speaking minority in the Baltic States' (see Russian MFA Department for Information and Press commentary, 20 May 2005). On 7 June 2005, the head of the Russian delegation to the PACE Konstantin Kosačev characterized the resolution of the European parliament as 'an act of interference in the domestic affairs of the Republic of Mari El and of the entire Russian Federation' and prevented the release of a report on the Mari to the PACE plenary. The State Duma in its declaration also denounced the resolution, blaming the European Parliament for the 'unsubstantiated nature of criticism' and 'double standards' in minority protection (see Declaration, 10 June 2005).

Despite the official denial of validity of the international criticism, the authorities attempted to show improvements in the situation to diffuse the damage brought by the international scandal (see Prina 2015: 77). The State Duma reproduced in its declaration the data of the republic's presidential administration that the share of ethnic Mari in the top positions within state and municipal service had increased from $26.9 \%$ to $32.6 \%$ between 2002 and 2005 (Sbornik 2005: 42-43). A lack of transparency in sources for the official data prevents its verification. In the unlikely event that the data is correct, it must be noted that these were mostly municipal civil servants, while the share of ethnic Mari at the republic level was much lower (see Zamyatin 2015).

To address 'the problem of a lack of positive information about the Russian regions abroad', presentations about Mari El were arranged in the Russian diplomatic premises in Helsinki and Tallinn. In March 2006, the Russian Embassy in Finland and the Finnish parliament's Russia Friendship Group organized a seminar on minority and indigenous rights. Minister of culture of Mari El Mihail Vasjutin attended the event and provided some data about the support for the Mari culture but avoided commenting on the human rights violations (Mika Parkkonen, Helsingin Sanomat, 6 March 2006).

In May 2006, the Russian Federation assumed chairmanship of the Committee of Ministers of the Council of Europe for the second half of 2006 with its first priority of 'reinforcing national human rights protection mechanisms, development of human rights education and protection 
of the rights of national minorities'. On 25 September 2006, Russia initiated the arrangement of a Finno-Ugric culture festival and, in October, a seminar entitled 'International legal guarantees for the protection of rights of national minorities and problems in their implementation' in Strasbourg.

On 17-18 October 2006, MEP Katrin Saks presented her report 'Situation of Finno-Ugric and Samoyed Peoples' to the PACE Committee on Culture, Science and Education. The Saks's report was singled out as a special target of Russian rebuke, both because of the high international profile of this document and the vulnerability of its scientific justification. In preparing their response, the Russian authorities engaged with the scientific community, attempting to substantiate their objection to the criticism (another paper is forthcoming on the scholarly representation of the conflict and the relations between Russian authorities and academia).

\section{Actions by the regional authorities aimed at dissolving organized dissent}

The regional authorities had not expected that crimes against ethnic leaders and activists would provoke such publicity, going well beyond the borders of the region. The first response of the republic's authorities was to reanimate an alternative national organization, Mari National Congress. The Congress, together with two other organizations, sent an appeal to Europarliamentarians, claiming that their resolution was 'not consistent with the reality' because 'the state [had] created in the Republic of Mari El the necessary conditions for the free development of the titular nation' (see Appeal, 25 May 2005). The appeal was presented 'in the name of the general public', thus claiming the legitimacy to represent those on whose behalf the European Parliament acted. Notably, the appeal was submitted to the republic's presidential administration, which distributed it.

Some leaders of factions represented in the republic's legislature assessed the European Parliament's actions as 'heavy-handed interference' based on 'mistaken information'. They supposed that 'the initiators of an information war against Mari El were certain political and nationalistic forces within the republic' (see Declaration, 30 May 2005). The declaration appeal targeted mostly a domestic audience by portraying the political opponents as 'unpatriotic' and even 'treacherous'. This document also was distributed by the republic's presidential administration, which was probably behind the documents. 
Discredited and delegitimized by the authorities, protest activities still continued but their intensity took a downward turn. On 4-5 June 2005, another extraordinary congress was held at a sacred site, where participants condemned Markelov's regime but supported Putin's policy (Nyman 2006: 50). Mari Ušem continued appealing to foreign audiences, sending open letters, for example, to Finnish president Tarja Halonen (1 August 2005). On 14 August 2005, Mari Ušem arranged another rally that was allowed by the authorities, probably because of an international event on the following day that attracted scrupulous international attention. Five years earlier, Yoshkar-Ola had been selected as the venue of the Tenth Congress of Finno-Ugric Studies (CIFU X).

On 15 August 2005, president Markelov greeted the Congress in person. Ambassadors from Estonia, Finland and Hungary in Russia attended the event. At the same time, law enforcement agencies tried to prevent contacts of foreign participants with Mari leaders and activists (Nyman 2006: 51). Before the Congress, on 6 July 2005, Congress president Jurij Anduganov was killed in a car accident under suspicious circumstances similar to those in which the republic's most known human rights activist Viacheslav Paidoverov was killed in winter 2001 (see Zamyatin 2015: 371).

Despite international criticism, the practice of the intimidation, defamation and marginalization of the opposition leaders continued. In August 2005, a criminal charge was initiated against Gennadii Pirogov after his speech at the rally of Mari Ušem, in which he allegedly slandered president Markelov (Doklad 2007: 139-140). In September 2005, the newspaper $K u d o+K o d u$ was pressed to leave its premises in the House of Press due to unpaid bills and a criminal case was initiated against its editor-in-chief Vladimir Kozlov that was later dropped (Doklad 2005: 10). In spring 2006, a criminal charge was initiated against the leader of the city community of the Mari traditional religion Vitalij Tanakov for 'incitement of interethnic enmity' in his religious brochure that the public prosecutor sought to classify as a piece of 'extremist literature' (Doklad 2006: 155-156; Doklad 2007: 137-139). A criminal charge was also filed and later dropped against the leader of Mari Ušem Nina Maksimova because she had disseminated Tanakov's brochure.

Violent attacks against ethnic leaders and activists continued. On 27 August, Vasilij Petrov, a former leader of the MAFUN, was beaten by perpetrators who remain unknown (see Doklad 2006: 155; Nyman 2006: 53). In January 2007, Vladimir Kozlov's wife Galina was beaten. Needless to 
say, the perpetrators of that crime were not found either. The European Parliament passed another resolution in her defense (Doklad 2007: 137).

Defending victims of human rights violations became very difficult. The head of the republic's presidential administration chaired the commission on human rights, which remained inactive (Doklad 2006: 164). In 2000, the post of the regional Ombudsman for Human Rights was instituted as a public authority structure, but until recently, it had remained vacant. In 2006, some independent regional human rights organizations were forced to cease their operations (Doklad 2007: 151).

The situation with the freedom of press became critical in Mari El also in comparison to other regions (Doklad 2007: 132, 136). By 2006, the last independent newspapers in the republic were closed. The informationanalytical department of the presidential administration established full control of all media, right down to the outlets in localities, and began to sanction the media content so that no trace of public criticism was left towards the republic's leadership. In addition to a monopoly in printed media, the administration also strived to control the internet. For example, access to some resources in Russia, such as the Estonia-based website MariUver, was blocked from June 2005 (see Nyman 2006: 36).

In September 2005, Mari Ǔ̌em was evicted from its premises, technically for a failure to pay for utilities. The LDPR regional leader urged the public prosecutor's office to put activities of Mari Ušem and Mer Kayaš on hold for being 'nationalist' (see Nyman 2006: 50). In 2006, authorities tried without success to close Mari Ǔ́em on formal grounds for a breach of the legislative requirement of registration (Doklad 2006: 155, 158; Doklad 2007: 138).

Finally, the Grey House succeeded in establishing control over the national movement after a takeover of Mer Kayaš, which was perceived on all sides as the legitimate interest group of the Mari, unlike the Mari National Congress. In 2008, at the next ordinary Congress of the Mari People, the Grey House managed to push through the appointment of their proxy to the leadership of Mer Kayaš (Zamyatin 2015: 377-378). Mer Kayaš thus became an element of the system of state control over interest groups that typically characterizes authoritarian regimes. Thus, the authorities subordinated the ethnic network through clientelist linkage to the 'power vertical'. At that, the practice of co-optation as a tool of ethnic control coexisted with assimilationist education policy (for details, see Zamyatin 2015: 383-384). 


\section{Conclusion}

The social and political situation in Mari El in the 1990s was relatively favorable for the authorities in achieving the policy goal of 'the preservation of accord in inter-ethnic relations' in terms of controlling the underlying conflictual factors despite social change. Among the structural factors, the ethnic composition, with ethnic groups of nearly equal size in the population, contained some space for conflict. The varying pace of modernization of the groups resulted in stratification based on overlapping ethnic and social cleavages. Social inequality and unequal opportunities were the issues with mobilizing potential. However, the general prevalence of elite politics over mass politics in the republic as well as the common origin and interests of regional elite vis-à-vis the federal center also made it possible to sustain a level of consensus regarding the ethnic issues and prevented the incentives for any elite segment to capitalize on mass support. Despite some deficiencies in the democratic functioning of political institutions, informal power sharing between the ethnic communities withstood the change in leadership and ensured 'interethnic harmony' in elite politics and intergroup politics.

The change in the republic's leadership in 2000 introduced authoritarian tendencies that led to the concentration of power in the hands of a new ruling group. Those who became the ruling elite initiated the redistribution of political and material resources at the expense of functionaries of the previous administration. The situation developed from attempts of regional political elites to reach a deal behind the closed doors into open confrontation between the power holders and the opposition. Among the many functionaries who lost their posts, also members of the titular elite were deprived of the access to political resources. In effect, the power grab downgraded the position of the titular elite. Perception and representation of the resource redistribution as the denial of the titular group's access to power added an ethnic dimension, as the forefront of the confrontation went along the ethnic lines.

Therefore, the building-up of an authoritarian regime in Mari El in the early 2000 s became the proximate cause for the emergence of the ethnopolitical conflict between the power holders and the political opposition, where the latter categorized itself in ethnic terms. Government actions directed at narrowing the position of the Mari language and culture in the public sphere triggered the conflict and helped the opposition to frame it 
as an ethnic one. However, this was an elite-level conflict internally driven by power struggle. The subject matter of the conflict was the access to the political system and the issue of political participation. The indicators of the conflict were expressions of elite frustration and mass protests, coercive actions of authorities and incidents of violence against ethnic leaders and activists. The political persecutions and repressions as well as the crackdown on the press contributed to the intensification of the conflict. While rhetoric about the persecutions dominated public discourse, at the core of the conflict was the problem of inadequate political participation. The perception of disproportional ethnic representation drove those who found themselves in a disadvantaged position after losing the elections to characterize the confrontation in ethnic terms.

The instrumentalist understanding of the conflict as one driven by power struggle of elites succeeds in revealing the dynamics of ethnic politics in the activities of political elites and leaders at the individual level of analysis. However, the institutional account provides a better explanation at the domestic level of the analysis. Initially, this was an institutional conflict, because the monopolization of power was not accompanied by major institutional changes. The titular elite did not seek to overthrow the institutional arrangements but to stick to the unwritten pact that ensured power sharing hitherto. Only after the failure of negotiations did the titular elite choose the strategy of the politicization of ethnicity in an attempt to mobilize popular support. Under the conditions of the ban on ethnic parties, the opposition was not formed as an institutionalized force in party politics. The authorities controlled mass media and blocked the spread of information about the events to a broader audience. Having been marginalized, the opposition could not use institutional channels and resources, and therefore responded through unconventional political actions.

For a number of reasons, the elite was not able to ignite underlying problems and inspire ethnic mobilization. The opposition side was represented by national organizations that were able to organize some instances of mass protest. These, however, were relatively innumerous and short-lived. Elitist politics alienated the people, most of whom preferred non-participation to engaging in unconventional participation. Weak links between the people and the elite were predetermined by a lack of popular motivation to demand for rulers to represent the ruled. The attempt at mobilization based on particularist ideology excluded the support of the groups of institutionalized opposition forces. Further, the elite 
was not able to present convincing incentives for the masses to join under the conditions of the improving economic situation of the early 2000 . Finally, economic growth legitimized the regime and diminished the appeal of the social inequality agenda led by the communists. The economic growth also allowed for rebuilding of a strong state that had the capacity to prevent popular mobilization and maintain intra-state security.

Unable to ignite ethnic mobilization, the titular elite also turned to the strategy of escalating the conflict by drawing attention to it on the international arena. The hope was that the federal center would replace the person in the office of the president of the republic, who was embroiled in the center of an international scandal. However, the Russian authorities declared the acts, like the European Parliament resolution, 'an intrusion into internal affairs' and backed the position of the republic's authorities against the opposition inside the republic. The mistake of this strategy was not seeing the authoritarian tendencies at the center and in regions as a single process. The consolidation of the authoritarian regime in Mari El took place simultaneously with the authoritarian turn in the center. While the foreign policy considerations might have been crucial, the Kremlin unambiguously backed Markelov, primarily because he proved his loyalty by not opposing but rather enhancing the Kremlin's recentralization agenda and governed the region as an exemplary client to the Moscow patron. Consequently, he keeps the office to this day.

A high level of coordination between central and regional authorities as well as controlled interest groups (and academic institutions, for that matter) in their response to international criticism was publicly displayed. The Kremlin's support gave a free hand to president Markelov to use authoritarian methods in suppressing organized political dissent. That is to say, the documented use of coercive methods is only the tip of the iceberg, and not all incidents of violence became publicly known. The securitization of minority issues led to the emergence of the 'atmosphere of fear' in the republic, in the words of one opposition leader, and one can only guess how much harassment ordinary activists experience. The conflict ended with the takeover of national organizations, which deprived the opposition of institutional channels to organize protests. The system of state corporatism was easy convertible into a system of state control under the authoritarian regime also in the sphere of ethnic relations.

Without the adherence to ethnic pluralism in the public domain, the republic ceased to be the tool of self-governance of the titular group. The 
dislocation of the balance of power between the ethnic communities amounted to the substitution of power sharing with ethnic domination as the method of diversity management. A question not discussed in this paper is whether ethnic domination was established intentionally or due to negligence. The method of diversity management was not so much the result of a deliberate choice as one of power politics. The formation of a new ruling group with the leader from outside coming with his team might have resulted in the establishment of ethnic domination as a by-product. At the same time, the leader's membership in the LDPR and some public statements from him and his cronies point to reliance on this method as a rational choice. Under a dual balance of power, the political regime based on power sharing was unstable because it inspired the 'winner takes all' strategy.

Therefore, the reliance of the authorities on ethnic domination as one of the methods of consolidating an authoritarian regime in the republic, which, in turn, caused the ethnopolitical conflict, was the result of regional political developments. At the same time, the new republic's leadership was confident that by imposing consolidation by authoritarian means, it acted on behalf of the Kremlin's recentralization agenda and, thus, could rely on its support. The Kremlin permitted the imposed regime consolidation despite the cost for inter-ethnic relations, inter alia, because it was unlikely to produce a communal conflict. In the long run, containing the conflict through authoritarian means has not removed the underlying structural factors. A new wave of democratization would reintroduce ethnic mobilization as an available political strategy and reopen the challenge of diversity management.

Konstantin Zamyatin Department of Finnish, Finno-Ugrian and Scandinavian Studies University of Helsinki, Finland

\section{Acknowledgements}

Research for this article was made possible by a scholarship from the Kone Foundation. 


\section{References and sources}

\section{References}

Alexander, James 2004: Federal Reforms in Russia: Putin's Challenge to the Republics. - Demokratizatsiya 12 (2). 233-263.

BAHry, Donna 2002: Ethnicity and Equality in Post-Communist Economic Transition: Evidence from Russia's Republics. - Europe-Asia Studies 54 (5). 673-699.

Belokurova \& Denisova 2003 = Елена Белокурова \& Ольга Денисова: Республика Марий Эл: Хроника политической жизни Республики Марий Эл (1989-200о). - Регионы России. Хроника и руководители. Том. 8. Республика Марий Эл, Чувашская Республика, Республика Башкортостан. Под науч. ред. К. Мацузато. Издательство Уральского университета. Екатеринбург. 39-92.

Brahm, Eric 2003: Conflict Stages. - Beyond Intractability. G. Burgess \& H. Burgess (eds). Conflict Information Consortium, University of Colorado, Boulder. Available online at: <http://www.beyondintractability.org/essay/conflict-stages > .

Brown, Michael E. 2001: The Causes of Internal Conflict: An Overview. - Nationalism and Ethnic Conflict. M. E. Brown et al. (eds). MIT Press. Cambridge, MA. 3-25.

Doklad 2002 = Доклад 'О положении с правами человека на территории Республики Марий Эл за 2002 год'. - Региональные доклады о положении с правами человека в 2002 году. Московская Хельсинкская Группа. Москва.

Available online at: <www.mhg.ru/files/doklad2002/respmarel2002.doc $>$.

- 2003 = Доклад 'О положении с правами человека на территории Республики Марий Эл за 2003 год'. - Региональные доклады о положении с правами человека в 2002 году. Часть 1. Московская Хельсинкская Группа. Москва. Available online at: <http://www.mhg.ru/publications/36E1AEE>.

- 2004 = Доклад 'О положении с правами человека на территории Республики Марий Эл за 2004 год. - Докладь региональных НПО о ситуации с правами человека в субъектах РФ в 2004 году. Часть 2. Московская Хельсинкская Группа. Москва. Available online at: <http://www.mhg.ru/publications/3708D4E>.

- 2005 = Доклад 'О положении с правами человека на территории Республики Марий Эл за 2004 год’. - Доклады региональных НПО о ситуации с правами человека в субъектах РФ в 2005 году. Часть 2. Московская Хельсинкская Группа. Москва. Available online at: <http://www.mhg.ru/publications/54F3049>.

- 2006 = Республика Марий Эл. - Права человека в регионах Российской Федерации. Сборник региональных докладов. Часть 2. Московская Хельсинкская Группа. Москва. 150-163. Available online at: <http://www.mhg.ru/publications/ $\mathrm{A} 1 \mathrm{AD} 89 \mathrm{~A}>$.

- 2007 = Республика Марий Эл. - Права человека в регионах Российской Федерации. Сборник региональных докладов. Часть 2. Московская Хельсинкская Группа. Москва. 130-151. Available online at: <http://www.mhg.ru/publications/ A1AD971>.

DrobižEva 2002 = Леокадия Дробижева (ed.): Социальное неравенство этнических групп: представления и реальность. Aсаdетіа. Москва. 
FAUZER 2011 = Фаузер, Виктор: Финно-угорские народы в современном мире. Ежегодник финно-угорских исстедований 3. 111-125.

Gel'man, Vladimir 2010: The Dynamics of Sub-National Authoritarianism: Russia in Comparative Perspective. - The Politics of Sub-National Authoritarianism in Russia. V. Gel'man \& C. Ross. Ashgate. Farnham. 1-19.

- 2015: Authoritarian Russia: Analyzing Post-Soviet Regime Changes. University of Pittsburg Press. Pittsburg.

Giuliano, Elise 2011: Constructing Grievance. Ethnic Nationalism in Russia's Republics. Cornell University Press. Ithaca \& London.

Gorenburg, Dmitry 2003: Minority Ethnic Mobilization in the Russian Federation. Cambridge University Press. Cambridge \& New York, NY.

Gurr, Ted R. 1993: Minorities at Risk: A Global View of Ethnopolitical Conflict. United States Institute of Peace Press. Washington, DC.

- 1994: Peoples Against States - Ethnopolitical Conflict and the Changing WorldSystem: 1994 Presidential Address. - International Studies Quarterly 38 (3). 347-377.

Harff, Barbara \& Gurr, Ted R. 2004: Ethnic Conflict in World Politics. 2nd edition. Westview Press. Boulder.

Harris, Peter \& Reilly, Ben (eds) 1998: Democracy and Deep-Rooted Conflict: Options for Negotiators. International Institute for Democracy and Electoral Assistance. Stockholm.

Hroch, Miroslav 1993: From National Movement to the Fully-formed Nation. - New Left Review I (198). 3-20.

Horowitz, Donald 1985: Ethnic Groups in Conflict. University of California Press. Berkeley \& Los Angeles.

Jesse, Neal G. \& Williams, Kristen P. 2010: Ethnic Conflict: A Systematic Approach to Cases of Conflict. CQ Press. Washington, DC.

LallukKa, SePpo 2003: From Fugitive Peasants to Diaspora: The Eastern Mari in Tsarist and Federal Russia. Academia Scientiarum Fennica. Helsinki.

Lijphart, Arend 1977: Democracy in Plural Societies: A Comparative Exploration. Yale University Press. New Haven.

Marger, Martin N. 2011: Race and Ethnic Relations: American and Global Perspectives. 9th ed. Wadsworth. Belmont, CA.

Martin, Terry 2001: The Affirmative Action Empire: Nations and Nationalism in the Soviet Union, 1923-1939. Cornell University Press. Ithaca \& London.

McGarry, John, O'Leary, Brendan \& Simeon, Richard 2008: Integration of Accommodation? The Enduring Debate in Conflict Regulation. - Constitutional Design for Divided Societies: Integration or Accommodation? S. Choudhry (ed.). Oxford University Press. Oxford. 41-88.

Miall, HugH 2004: Conflict Transformation: A Multi-Dimensional Task. - Transforming Ethnopolitical Conflict: The Berghof Handbook. A. Austin, M. Fisher \& N. Ropers (eds). VS Verlag für Sozialwissenschaften. Wiesbaden. 67-89.

Nyman, Ann-Sofie (ed.) 2006: The Human Rights Situation of the Mari Minority of the Republic of Mari El: A Study of the Titular Nationality of One of Russia's Ethnic Regions. Joint Report of the International Helsinki Federation for Human Rights and the Moscow Helsinki Group. IHF. Vienna.

Available online at: <http://www.mhg.ru/files/engl/mariengl.pdf $>$. 


\section{Konstantin Zamyatin}

Osipov, Alexander 2011: The "Peoples' Congresses" in Russia: Failure or Success? Authenticity and Efficiency of Minority Representation. European Centre for Minority Issues, ECMI Working Paper 48. Available online at: <http://www.ecmi.de/publications/detail/48-the-peoples-congresses-in-russia-failure-or-success-authenticityand-efficiency-of-minority-representation-214/>

Otčët 2002 = Положение СМИ в Республике Марий Эл. Отчёт участников миссии Фонда защиты гласности о поездке в Йошкар-Олу (9-11 декабря 20о2). Available online at: $\langle$ http://www.gdf.ru/mission/item/1/21 $>$.

Prina, Federica 2015: National Minorities in Putin's Russia: Diversity and Assimilation. Routledge. London.

SANUкоV 2005 = Ксенофонт Сануков: Марийская автономия. Марийское книжное издательство. Йошкар-Ола.

Sbornik 2005 = Сборник материалов об этнической ситуаиии в Республике Марий Эл и соииально-культурном положении марийского народа. Информационноаналитическое управление Администрации Президента Республики Марий Эл. Йошкар-Ола.

Snetkov, Aglaya 2015: Russia's Security Policy Under Putin: A Critical Perspective. Routledge. London.

ŠArov 2005 = Шаров, Владимир: Марий Эл. - Этнополитическая ситуация и конфликты в государствах СНГ и Балтии. Ежегодный доклад, 2004. В. Тишков \& Е. Филиппова (ред.). Институт этнологии и антропологии РАН. Москва. 199-206.

- 2007 = Шаров, Владимир: Марийцы в Республике Марий Эл: депопуляция или несовершенство переписи? - Этнокультурный облик России: перепись 20022. В. Степанов \& В. Тишков (ред.). Наука. Москва. 151-164.

Tiškov 2005 = Тишков, Валерий: Как делаются провокации (по поводу положения финно-угорских народов России). - Бюллетень сети этнологического мониторинг и раннего предупреждения конфликтов. EAWARN 59. 1-3.

Umland, Andreas 2013: New Extreme Right-Wing Intellectual Circles in Russia: The Anti-Orange Committee, the Izborsk Club and the Florian Geyer Club. - The Russian Analytical Digest (135). 2-5.

Wimmer, Andreas, Cederman, Lars-Erik \& Min, Brian 2009: Ethnic Politics and Armed Conflict. A Configurational Analysis of a New Global Dataset. - American Sociological Review 74 (2). 316-337.

Wolff, Stefan 2007: Ethnic Conflict. A Global Perspective. Oxford University Press. Oxford.

Zamyatin, Konstantin 2013: Official Status As a Tool of Language Revival? A Study of the Languages Laws in Russia's Finno-Ugric Republics. - Journal of Ethnology and Folkloristics 7 (1). 125-153.

- 2014: An Official Status for Minority Languages? A Study of State Languages in Russia's Finno-Ugric Republics. Finno-Ugrian Society. Helsinki.

- 2015: Minority Political Participation under Majority Domination: a Case Study of Russia’s Republic of Mari El. - Journal de la Société Finno-Ougrienne 95. 349-39o. 
- 2016a: Russian Political Regime Change and Strategies of Diversity Management: From a Multinational Federation towards a Nation-State. - Journal of Ethnopolitics and Minority Issues in Europe 15 (1). 19-49.

- 2016b: Power Sharing or Ethnic Domination? Approaches to Diversity Management in the Ethnic Republics of Russia in the Early 2010s. Paper presented at 16th Aleksanteri Conference 'Life and Death in Russia', 26 October 2016, Helsinki, Finland.

\section{Official documents and legal acts}

Appeal on Behalf of the Mari People, published on the web-site <http://www.ugri.info/ mari/> on 22 February 2005.

Resolution 'Violations of Human Rights and Democracy in the Republic of Mari El in the Russian Federation', adopted by the European Parliament on 12 May 2005.

Commentary of the Information and Press Department of the Ministry of Foreign Affairs of the Russian Federation Regarding the Adoption by the European Parliament of the Resolution on Violations of Human Rights and Democracy in the Republic of Mari El, Russian Federation, 20 May 2005 №1145.

Appeal of the National Public Associations of the Republic of Mari El to the Deputies of the European Parliament, 25 May 2005.

Declaration of the Leaders of Factions Represented in the State Assembly of the Republic of Mari El Regarding the Adoption by the European Parliament of the Resolution on Violations of Human Rights and Democracy in the Republic of Mari El, Russian Federation, 30 May 2005.

Declaration of the State Duma With Regard to the Adoption by the European Parliament of the Resolution on Violations of Human Rights and Democracy in the Republic of Mari El in the Russian Federation, 10 June 2005 №1980-IV.

Situation of Finno-Ugric and Samoyed Peoples. Rapporteur: Mrs. Katrin Saks, Estonia. Doc. 11087. 26 October 2006. Parliamentary Assembly of the Council of Europe, Committee on Culture, Science and Education. 